Bull. Egypt. Soc. Physiol. Sci. 38(2), 137- 148

\author{
Bull. of Egyp. Soc. Physiol. Sci. \\ (Official Journal of Egyptian Society for Physiological Sciences) \\ (pISSN: 1110-0842; eISSN: 2356-9514)
}

\title{
Targeting $\beta$-catenin and cytochrome p450 (1B1) by Ellagic Acid in Colon Cancer Cell Lines: Implications for Treatment Applications
}

\author{
1,2Omar S. El-Masry , 1'Amany I. Youssef \\ ${ }^{1}$ Department of Applied Medical Chemistry, Medical Research Institute, Alexandria University. \\ ${ }^{2}$ Department of Clinical Laboratory Sciences, College of Applied Medical Sciences, Imam Abdulrahman Bin Faisal University, P.Box. \\ 1982, Dammam, Saudi Arabia.
}

Received: 1 Jan 2018

Accepted: 27 Feb 2018

Available online: $1 \mathrm{~J}$ une 2018

\section{Keywords}

Ellagic acid

Colon cancer

$\beta$-catenin

Cytochrome (1B1)

\section{Abstract}

The knowledge is growing to address ellagic acid (EA) as a promising anti-cancer agent in colon, as well as, other types of human cancers. Up-regulation of $\beta$-catenin in colon cancer supports tumorigenic pathways in numerous aspects, which makes the need pressing to target this pathway. Likewise, cytochrome p450 (1B1) sustains carcinogenicity and tumor growth by either; activation of pro-carcinogens, or by inactivation of chemotherapeutic agents. Therefore overexpression of the enzyme has been reported in colon and other types of cancers. The effect of ellagic acid treatment on the level of total and phospho- $\beta$-catenin and cytochrome p450 (1B1) was estimated by enzyme-linked immunosorbent assay (ELISA) method in CaCo-2 and HCT-116 colon cancer cells. The influence of ellagic acid on cell proliferation and cell cycle progression was assessed using the CCK-8 kit and flow cytometry analysis, respectively. Results revealed that ellagic acid exhibited an anti-proliferative potential in both cell types, which was associated with increasing number of sub-G1 (apoptotic) cells and cell cycle arrest in G1 phase in ellagic acid-treated cells. This was in harmony with the ability of the drug to increase $\beta$-catenin phosphorylation (hence its degradation) and reduce cytochrome 1B1 levels in CaCo-2 and HCT-116 cell lines. These results altogether indicate that different cellular genetics (Ras oncogene and p53 status, in particular) had no impact on the anti-tumor effects of ellagic acid in this model

Corresponding author: Dr. Omar S. El-Masry , Department of Clinical Laboratory Science, College of Applied Medical Sciences, Imam Abdulrahman Bin Faisal University, Dammam, Saudi Arabia. Rakkah, 31443. Tel: +203 4282373, Fax: +203 4283719.E-mail: oselmasry@iau.edu.sa 


\section{Introduction:}

Colon cancer is a leading cause of death worldwide (1). Traditional treatment modalities have shown limited success to improve patients' quality of life, which makes a pressing need to innovate novel therapies exerting no harm on normal tissues. Ellagic acid (EA) has received a significant interest from researchers as a potential promising therapeutic agent for colon, as well, as other types of human cancers. Ellagic acid antiproliferative potential was reported in human colon cancer cell line model (2). Anti-cancer effects of ellagic acid include: induction of apoptosis; inhibition of angiogenesis; interference with DNA-carcinogen binding; anti-inflammatory and anti-viral effects, and overcoming drug resistance (3). Inhibition of mammalian target of rapamycin (mTOR) by ellagic acid in prostate cancer cells was also reported (4). Inhibition of breast cancer stem cells proliferation and migration potential was also reported following treatment with ellagic acid. This inhibition was associated with interruption of ACTN4/ $\beta$-catenin interaction and consequent degradation of $\beta$ catenin (5). B-catenin, a main component of Wnt pathway has been frequently reported to be mutated in chemically induced colon cancer in rats; the oncogene c-MYC and cyclin D1, a cell cycle regulator, are downstream targets of $\mathrm{Wnt} / \beta$ catenin pathway (6). It has also been reported that this pathway supports cancer initiation as well as progression (7). At this end, $\beta$-catenin has been recognized as a potential target for cancer chemoprevention in various cancer models including colon (8-10). Cytochrome 1B1 (CYP 1B1) is a xenobiotic metabolizing enzyme belonging to a large family of cytochrome p450 proteins. The enzyme has been shown to contribute to activation of numerous procarcinogens converting them to active carcinogens participating to human carcinogenesis. Hence, the enzyme has attracted attention as another therapeutic target in tumors that overexpress CYP 1B1 (11). CYP 1B1 was proposed as a promoting factor in human colon cancer. In this respect, it was reported that CYP 1B1 is overexpressed in colon cancer tissues as compared to the normal samples (12). Likewise, overexpression of CYP 1B1 was also reported in non-small cell lung cancer (NSCLC) highlighting the enzyme as a biomarker for disease progression (11). Inflammatory response has been involved in induction of CYP 1B1 in an in vitro model of colorectal cancer where treatment of HCT-116 and SW480 cells with interleukin 6 (IL-6) resulted in overexpression of the enzyme. This finding was also confirmed in clinical samples in which IL-6 was overexpressed when compared to the adjacent normal tissue samples (13).

The main aim of the current study was to investigate the effect of ellagic acid on $\beta$-catenin level and phosphorylation. In addition, the effect of ellagic acid on CYP 1B1 was also investigated. This investigation would help to assess the concordance between the anti-proliferative potential of ellagic acid and its potential to regulate cell migration and other cellular functions via regulation of $\beta$-catenin or CYP $1 \mathrm{~B} 1$ in two colon cancer cell lines with different genetic background.

\section{Material and methods:}

\section{Materials:}


CaCo-2 (K-Ras+/ p53-) and HCT-116 (K-Ras$/ \mathrm{p} 53+)$ colon cancer cell types were obtained from the Medical Technology Centre, Medical Research Institute, University of Alexandria, Egypt. Dulbecco's Minimal Essential Medium (DMEM (\#41965039)), Trypsin EDTA (\#25200056), Fetal Calf serum (FCS; \#16140071), and Phosphate buffered Saline (PBS; \#10010031) were all purchased from Gibco ${ }^{\mathrm{TM}}$, Paisly, UK. CCK-8 kit for assessment of cell proliferation was purchased from MOLEQULE-ON®, Auckland, New Zeeland. Beta-Catenin (Total/Phospho) InstantOne ELISA $^{\mathrm{TM}}$ Kit (\# 85-86143) was from Invitrogen ${ }^{\mathrm{TM}}$, Thermo Fisher Scientific, USA. Enzyme-linked Immunosorbent Assay Kit for Cytochrome p450 1B1 (CYP1B1) (\#SED297Hu) was obtained from Cloud-Clone Corp., Katy, Texas, USA. Propidium iodide (\#P4864) was purchased from SigmaAldrich ${ }^{\circledR}$ (now Merck), Darmstadt, Germany. Pierce $^{\mathrm{TM}}$ BCA Protein Assay Kit was from Thermo Fisher Scientific, USA.

\section{Methods:}

\section{1- Cell maintenance and sub- culture:}

CaCo-2 and HCT-116 colon cancer cell lines were grown as a continuous monolayer culture in appropriate tissue culture flasks, and were kept at $37^{\circ} \mathrm{C}$ and $5 \% \mathrm{CO}_{2}$ in a humidified atmosphere. Cell sub-culture was performed at approximately $80 \%$ confluence to maintain culture of cells for preparation of experiments and freezing of stocks.

\section{2- Cell proliferation:}

CaCo-2 and HCT-116 were sub-cultured; counted and $1 \times 10^{4}$ cells were then seeded in triplicate sets in a 96-well tissue culture plate (final volume $=100 \mu \mathrm{l}$ ). A set of wells containing DMEM were used as the double negative control. The plate was incubated at $37^{\circ} \mathrm{C}$ and $5 \% \mathrm{CO}_{2}$ overnight to allow adherence of cells. The next day, cells were treated with increasing doses of ellagic acid $(0-200 \mu \mathrm{g} / \mathrm{ml})$ making the final volume up to $150 \mu 1 /$ well. A set of wells containing cells was used as the single negative control cells and were treated with DMEM only; likewise, DMEM was added to the double negative control wells so the final volume in all wells is $150 \mu$ l. Treated plates were then incubated at the previously mentioned conditions for 72 hours. Cell proliferation was then estimated by adding $10 \mu \mathrm{l}$ of the CCK 8 dye to all experimental wells followed by an incubation period of 1-2 hours at the same culture conditions. Cell proliferation was represented as negative dose response curves showing cell proliferation in each treated well as a percentage from the corresponding negative control cells ( $100 \%$ cell proliferation).

\section{3- Cell cycle analysis:}

Cells were sub-cultured; counted, and plated in tissue culture petri dishes at a density of $1 \times 10^{6}$ cells/dish. Cells were then incubated overnight to adhere or equilibrated at the same culture conditions for 2 hours as zero-time cells. This population of cells were then trypsinized and detached then washed twice by being spun in ice-cold PBS for 5 minutes at 1000 RPM. Cells were then permeabilized in $70 \%$ ethanol overnight at $4{ }^{\circ} \mathrm{C}$. Permeabilized cells were then washed as previously mentioned and were suspended in $300 \mu 1$ of propidium iodide before being incubated overnight at $4^{\circ} \mathrm{C}$. The emission spectra of PI of stained cells were then analyzed 
at FL2H and FL3H filters of the flow cytometer for cell cycle progression analysis classifying cells into 4 classes in different cell cycle phases based on their DNA content (Sub-G1, G1, S (synthetic) and $\mathrm{M}$ (mitotic)). Control and ellagic acid-treated $(50 \mu \mathrm{g} / \mathrm{ml})$ cells were incubated at the same culture conditions for 48 hours before being analyzed in the same way as zero-time cells.

\section{4- Assessment of $\beta$-catenin and cytochrome 1B1 by ELISA:}

Cells were sub-cultured. Counted and $1 \times 10^{6}$ cells were seeded in $10 \mathrm{~cm}$ cell culture Petri dishes then incubated overnight at standard tissue culture conditions to adhere. The next day, old medium was removed and cells were incubated with fresh medium or ellagic acid (30 or $100 \mu \mathrm{g} / \mathrm{ml}$ ) for 24 hours. Cells were then washed with ice-cold PBS and incubated with ice-cold lysis buffer for 30 minutes on ice. Lysed cells were then detached using cell scrapers and centrifuged at the maximum speed in a cooling centrifuge. Protein concentration was estimated in cell lysate. Control and treated samples (diluted 10 times) along with positive and negative controls were loaded into wells of the 96-well pre-coated ELISA plate in triplicate sets. The procedure was followed as described in the datasheet of the beta-Catenin (Total/Phospho) InstantOne ELISA ${ }^{\mathrm{TM}}$ Kit (\# 85-86143; Invitrogen $^{\mathrm{TM}}$, Thermo Fisher Scientific, USA.). Change in absorbance reflects the levels of total and phospho- $\beta$ catenin in cell lysate. Cytochrome 1B1 levels were estimated in cell lysate according to the procedure described in the datasheet of Enzyme-linked Immunosorbent Assay Kit for Cytochrome P450 1B1 (CYP1B1; detection range is $1.56-100 \mathrm{ng} / \mathrm{ml}$ ) (\#SED297Hu; Cloud-Clone Corp., Katy, Texas, USA.).

\section{5- Statistical analysis:}

Statistical comparisons were done using student ttest and difference between pairs was considered statistically significant when $p$ values are $\leq 0.05$. Data analysis was done using Graphpad Prism (version 7; CA, USA.)

\section{Results:}

1- Cell proliferation: Increasing doses of ellagic acid resulted in a significant reduction in HCT-116 and $\mathrm{CaCo-2}$ cell proliferation:

Incubation of HCT-116 (Figure 1 and table 1) and CaCo-2 (Figure 1 and table 2) colon cancer cells with ellagic acid $(0-200 \mu \mathrm{g} / \mathrm{ml})$ for 72 hours produced a significant reduction in cell proliferation when compared to the negative control (100\% cell proliferation; data and $\mathrm{p}$ values are summarized in tables 1 and 2). The reduction in cell proliferation was obvious at higher con centration of the drug, and the response of both cell lines was similar at low concentrations (0$12.5 \mu \mathrm{g} / \mathrm{ml}$ ), as well as at the highest dose $(200 \mu \mathrm{g} / \mathrm{ml})$. Overall, CaCo-2 cells seemed to be more responsive; however, this difference between the responses of both cell lines was not statistically significant (Figure 1 and tables 1 and 2).

2- Ellagic acid induced cell cycle arrest and an apoptotic insult as revealed by flow cytometric analysis: 
Flow cytometric analysis of cell cycle progression in EA-treated and untreated cells along with zerotime cell population revealed the potential combined static and apoptotic influence of the drug on HCT-116 (Figure 2A and tables 3) and CaCo-2 cells (Figure $2 \mathrm{~B}$ and table 4). Most of zero-time and control cells in both cell types were in $\mathrm{G} 1$ phase with some proportions enter into $\mathrm{S}$ and G2M phases. Treatment of cells with ellagic acid $(50 \mu \mathrm{g} / \mathrm{ml})$ and incubation for 48 hours resulted in an apparent increase in the number of sub-G1 cell population; this was significant (in CaCo-2 only) when compared to the corresponding cell population of zero-time $(\mathrm{p}=$
0.038) and control CaCo-2 cells $(\mathrm{p}=0.0287)$. In HCT-116 cells, the number of sub-G1 cell population in EA-treated cells was apparently increased in comparison to zero-time and control cells, thought the difference was not statistically significant $(\mathrm{p}=0.057)$. The difference between the number of cells in the G1 phase of zero-time and control cell populations was not significantly different from their corresponding G1 phase cells in treated $\mathrm{CaCo}-2$ and HCT-116 cells. These results suggest that the anti-proliferative influence of EA in these cell lines (Figure 1) may be owed to both static and apoptotic modes of action as confirmed by cell cycle analysis (Figure 2).

Table 1: Cell proliferation data (mean \pm S.D) in control and EA-treated HCT-116 cells (p values are for comparisons against control).

\begin{tabular}{|c|c|c|c|c|c|c|c|c|c|}
\hline $\begin{array}{c}\text { Experiment } \\
\text { number }\end{array}$ & \multicolumn{7}{|c|}{ Ellagic acid concentration $(\boldsymbol{\mu g} / \mathrm{ml})$} \\
\hline & 0 & $1 \mu \mathrm{g} / \mathrm{ml}$ & $5 \mu \mathrm{g} / \mathrm{ml}$ & $10 \mu \mathrm{g} / \mathrm{ml}$ & $15 \mu \mathrm{g} / \mathrm{ml}$ & $25 \mu \mathrm{g} / \mathrm{ml}$ & $50 \mu \mathrm{g} / \mathrm{ml}$ & $100 \mu \mathrm{g} / \mathrm{ml}$ & $200 \mu \mathrm{g} / \mathrm{ml}$ \\
\hline $\mathbf{1}$ & 100 & 98.43 & 89.95 & 83.78 & 79.81 & 74.54 & 77.5 & 59.3 & 43.8 \\
\hline $\mathbf{2}$ & 100 & 95.4 & 98.42 & 91.06 & 85.4 & 76.19 & 76.1 & 64.1 & 49.6 \\
\hline $\mathbf{3}$ & 100 & 97.6 & 94.36 & 89.3 & 81.6 & 83.12 & 79.3 & 70.05 & 39.25 \\
\hline Mean \pm S.D & $\mathbf{1 0 0} \pm \mathbf{0}$ & $\mathbf{9 7 . 1 4} \pm \mathbf{1 . 5 6}$ & $\mathbf{9 4 . 2 4} \pm \mathbf{4 . 2 3}$ & $\mathbf{8 8 . 0 5} \pm \mathbf{3 . 8}$ & $\mathbf{8 2 . 2 7} \pm \mathbf{2 . 8 5}$ & $\mathbf{7 7 . 9 5} \pm \mathbf{4 . 5 5}$ & $\mathbf{7 7 . 6 3} \pm \mathbf{1 . 6}$ & $\mathbf{6 4 . 4 8} \pm \mathbf{5 . 3 8}$ & $\mathbf{4 4 . 2 2} \pm \mathbf{5 . 1 8}$ \\
\hline $\mathbf{p}$ value & & $\mathbf{0 . 0 8 7 2}$ & $\mathbf{0 . 1 4 2 8}$ & $\mathbf{0 . 0 3 2 0}$ & $\mathbf{0 . 0 0 8 5}$ & $\mathbf{0 . 0 1 3 9}$ & $\mathbf{0 . 0 0 1 7}$ & $\mathbf{0 . 0 0 7 6}$ & $\mathbf{0 . 0 0 2 9}$ \\
\hline
\end{tabular}

Table 2: Cell proliferation data (mean \pm S.D) in control and EA-treated CaCo-2 cells ( $p$ values are for comparisons against control).

\begin{tabular}{|c|c|c|c|c|c|c|c|c|c|}
\hline Experiment & \multicolumn{9}{|c|}{ Ellagic acid concentration $(\mu \mathrm{g} / \mathrm{ml})$} \\
\hline & 0.0 & $1 \mu \mathrm{g} / \mathrm{ml}$ & $5 \mu \mathrm{g} / \mathrm{ml}$ & $10 \mu \mathrm{g} / \mathrm{ml}$ & $15 \mu \mathrm{g} / \mathrm{ml}$ & $25 \mu \mathrm{g} / \mathrm{ml}$ & $50 \mu \mathrm{g} / \mathrm{ml}$ & $100 \mu \mathrm{g} / \mathrm{ml}$ & $200 \mu \mathrm{g} / \mathrm{ml}$ \\
\hline 1 & 100 & 98.2 & 94.15 & 88.4 & 79 & 75.8 & 52.7 & 48.3 & 38.6 \\
\hline 2 & 100 & 96.1 & 91.5 & 91.05 & 82.8 & 70.4 & 57 & 40.9 & 42.4 \\
\hline 3 & 100 & 92.9 & 97.3 & 93.7 & 86.01 & 69.2 & 61.2 & 47.2 & 36.1 \\
\hline Mean \pm S.D & $\begin{array}{c}100 \\
\pm 0\end{array}$ & $95.73 \pm 2.7$ & $94.32 \pm 2.9$ & $\begin{array}{r}91.05 \\
\pm 2.65\end{array}$ & $82.6 \pm 3.5$ & $71.8 \pm 3.51$ & $\begin{array}{l}56.97 \\
\pm 4.25\end{array}$ & $45.47 \pm 4.0$ & $\begin{array}{r}39.03 \\
\pm 3.17\end{array}$ \\
\hline p value & & 0.12 & 0.077 & 0.028 & 0.0133 & 0.005 & 0.003 & 0.002 & 0.0009 \\
\hline
\end{tabular}


3- Incubation of CaCo-2 and HCT-116 cells with

ellagic acid increased $\beta$-catenin
phosphorylation:

Figure $3 \mathrm{~A}$ and $\mathrm{B}$ and tables 5 and 6 depicts the effect of incubating HCT-116 and CaCo-2 cells with ellagic acid (30 or $100 \mu \mathrm{g} / \mathrm{ml}$ ) for 24 hours on total and phospo- $\beta$-catenin. Results showed the ability of ellagic acid to cause an obvious increase in $\beta$-catenin phosphorylation when compared to the control untreated cells as revealed by higher absorbance values. Significant increase was observed at higher concentration in HCT-116 ( $\mathrm{p}=$ 0.0002) and CaCo-2 ( $=0.0001)$ cells. Lower concentration of the drug also elicits a significant elevation in $\beta$-catenin phosphorylation in HCT-116 cells $(p=0.017)$, while this effect was more significant in $\mathrm{CaCo}-2$ cells $(p=0.0008)$. There was no remarkable change in the absorbance values for total $\beta$ catenin in treated cells when compared to the basal levels in the control cells in both cell types $(\mathrm{p} \geq 0.05)$. These observations indicate that ellagic acid may help to trigger $\beta$-catenin phosphorylation, an event that signals degradation process of this protein. Of note, the basal level of phospho $\beta$-catenin in HCT-116 cells was higher than that in $\mathrm{CaCo}-2$ cell line (tables 5 and 6; data are means of triplicate sets).
Figure 1: Effect of ellagic acid on HCT-116 and CaCo2 cell proliferation. The negative dose response curve depicted in Figure 1 indicated that increasing concentrations of ellagic acid resulted in a significant inhibition of HCT-116 and CaCo- 2 cell proliferation when compared to the corresponding negative control ( $100 \%$ cell proliferation). The anti-proliferative effect was superior at higher concentrations and $\mathrm{CaCo}-2$ cells appeared to be more sensitive than HCT-116 cells (results are presented as the mean \pm S.D of 3 independent experiments). $*=\mathrm{p} \leq 0.05, * *=\mathrm{p} \leq 0.01$ and $* * *=p \leq 0.001$.

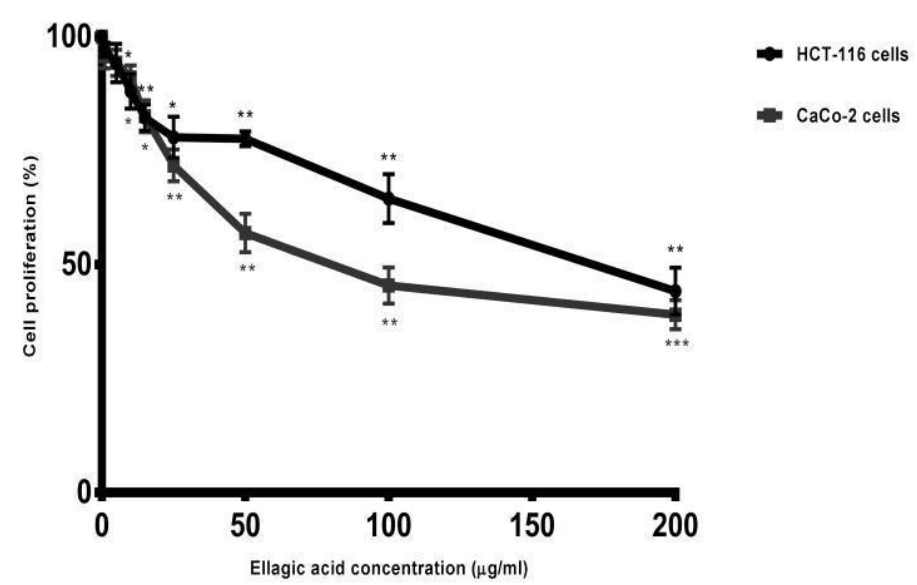

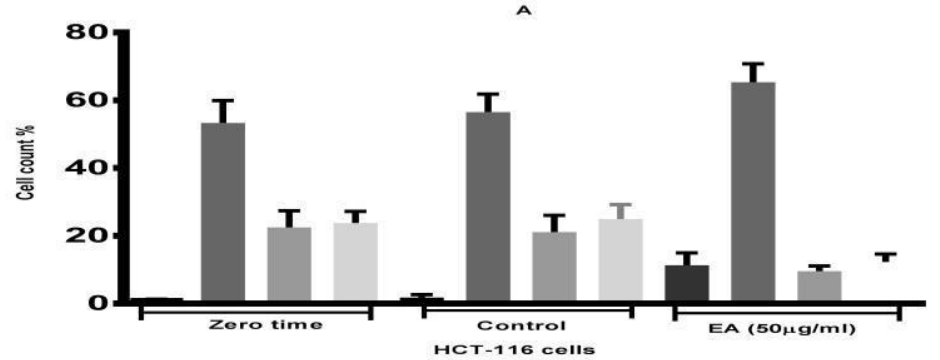

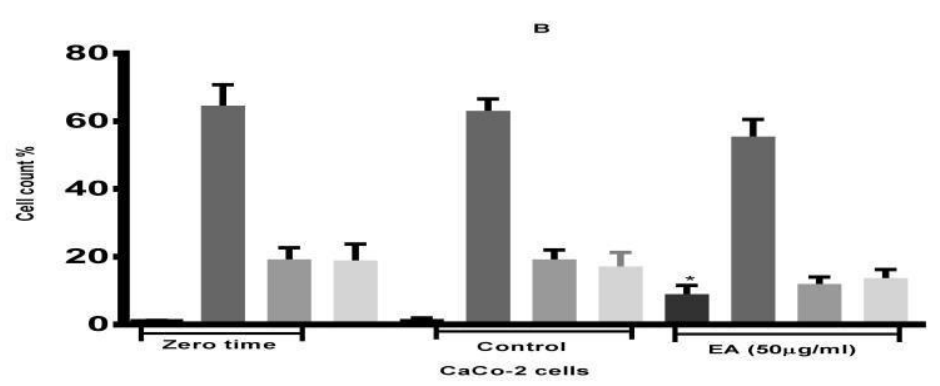

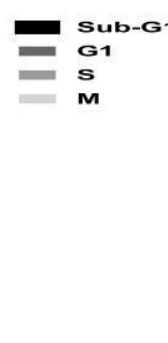

Figure 2: Effect of ellagic acid on cell cycle progression in HCT-116 and $\mathrm{CaCo}-2$ cell lines. Incubation of HCT-116 cells (A) with ellagic acid $(50 \mu \mathrm{g} / \mathrm{ml})$ for 48 hours resulted in an apparent, but not significant increase in the number of sub-G1 cells when compared to the corresponding cell population in zero-time or control cells $(\mathrm{p}=0.057)$. There was no significant difference between the number of G1 phase cells in zero-time or control cells and ellagic acid-treated cells suggesting cell

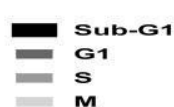
cycle arrest at this point. A similar effect was observed in $\mathrm{CaCo}-2$ cells (B) with a significant increase in the number of cells in sub-G1 phase in comparison to the corresponding control or zero-time cells $(\mathrm{p}=$ 0.0287 and 0.038). * $=\mathrm{p} \leq 0.05 \quad(\mathrm{n}=3$ independent experiments). 
Table 3: Cell cycle analysis data (mean \pm S.D) in control and EA-treated HCT-116 cells.

\begin{tabular}{|c|c|c|c|c|c|c|c|c|c|c|c|c|}
\hline & \multicolumn{4}{|c|}{ Zero-time cells } & \multicolumn{4}{|c|}{ Control cells } & \multicolumn{4}{|c|}{ EA-treated cells $(50 \mu \mathrm{g} / \mathrm{ml})$} \\
\hline $\begin{array}{c}\text { Experiment } \\
\text { number }\end{array}$ & $\begin{array}{l}\text { Sub- } \\
\text { G1 }\end{array}$ & G1 & $\mathbf{S}$ & M & Sub-G1 & G1 & $\mathbf{S}$ & M & $\begin{array}{c}\text { Sub- } \\
\text { G1 }\end{array}$ & G1 & $\mathbf{S}$ & $\mathbf{M}$ \\
\hline 1 & 0.91 & 52.23 & 20.12 & 22.8 & 1.54 & 57.55 & 21.06 & 29.5 & 8.15 & 66.8 & 11.25 & 12.3 \\
\hline 2 & 1.32 & 60.4 & 28.12 & 27.6 & 2.71 & 50.79 & 16.14 & 21.04 & 10.45 & $\begin{array}{c}59.3 \\
5\end{array}$ & 9.23 & 14.6 \\
\hline 3 & 0.895 & 47.25 & 19.25 & 20.93 & 1.09 & 61.23 & 26.03 & 24.32 & 15.32 & $\begin{array}{c}69.9 \\
1\end{array}$ & 8.24 & 9.86 \\
\hline Mean \pm S.D & $\begin{array}{c}1.042 \\
\pm \\
0.24\end{array}$ & $\begin{array}{c}53.29 \\
\pm \\
6.64\end{array}$ & $\begin{array}{c}22.5 \\
\pm \\
4.88\end{array}$ & $\begin{array}{c}23.78 \\
\pm \\
3.441\end{array}$ & $\begin{array}{c}1.78 \\
\pm \\
0.83\end{array}$ & $\begin{array}{c}56.52 \\
\pm \\
5.29\end{array}$ & $\begin{array}{c}21.08 \\
\pm \\
4.94\end{array}$ & $\begin{array}{c}24.95 \\
\pm \\
4.26\end{array}$ & $\begin{array}{c}11.31 \\
\pm \\
3.66\end{array}$ & $\begin{array}{c}65.3 \\
5 \pm \\
5.42\end{array}$ & $\begin{array}{c}9.573 \\
\pm \\
1.53\end{array}$ & $\begin{array}{c}12.25 \\
\pm \\
2.37\end{array}$ \\
\hline
\end{tabular}

Table 4: Cell cycle analysis data (mean \pm S.D) in control and EA-treated CaCo-2 cells.

\begin{tabular}{|c|c|c|c|c|c|c|c|c|c|c|c|c|}
\hline & \multicolumn{4}{|c|}{ Zero-time cells } & \multicolumn{4}{|c|}{ Control cells } & \multicolumn{4}{|c|}{ EA-treated cells $(50 \mu \mathrm{g} / \mathrm{ml})$} \\
\hline $\begin{array}{l}\text { Experiment } \\
\text { number }\end{array}$ & Sub-G1 & G1 & $\mathbf{S}$ & M & Sub-G1 & G1 & $\mathbf{S}$ & M & $\begin{array}{c}\text { Sub- } \\
\text { G1 }\end{array}$ & G1 & $\mathbf{S}$ & $\mathbf{M}$ \\
\hline 1 & 1.23 & 71.25 & 18.4 & 17.14 & 1.32 & 67.02 & 19.25 & 21.8 & 6.45 & 61.25 & 10.21 & 16.2 \\
\hline 2 & 0.86 & 59.12 & 16.3 & 15.23 & 1.54 & 60.58 & 16.45 & 15.63 & 8.96 & 51.98 & 14.25 & 13.71 \\
\hline 3 & 0.692 & 63.5 & 23.01 & 24.36 & 1.98 & 61.7 & 21.97 & 13.98 & $\begin{array}{c}11.5 \\
3\end{array}$ & 53.2 & 11.39 & 11.21 \\
\hline Mean \pm S.D & $\begin{array}{c}0.9273 \\
\pm \\
0.2752\end{array}$ & $\begin{array}{c}64.62 \\
\pm \\
6.143\end{array}$ & $\begin{array}{c}19.24 \\
\pm \\
3.432\end{array}$ & $\begin{array}{c}18.91 \\
\pm \\
4.815\end{array}$ & $\begin{array}{c}1.613 \\
\pm \\
0.3361\end{array}$ & $\begin{array}{c}63.1 \\
\pm \\
3.441\end{array}$ & $\begin{array}{c}19.22 \\
\pm \\
2.76\end{array}$ & $\begin{array}{c}17.14 \\
\pm \\
4.122\end{array}$ & $\begin{array}{c}8.98 \\
\pm \\
2.54\end{array}$ & $\begin{array}{c}55.48 \\
\pm \\
5.037\end{array}$ & $\begin{array}{c}11.95 \\
\pm \\
2.077\end{array}$ & $\begin{array}{c}13.71 \\
\pm \\
2.495\end{array}$ \\
\hline
\end{tabular}
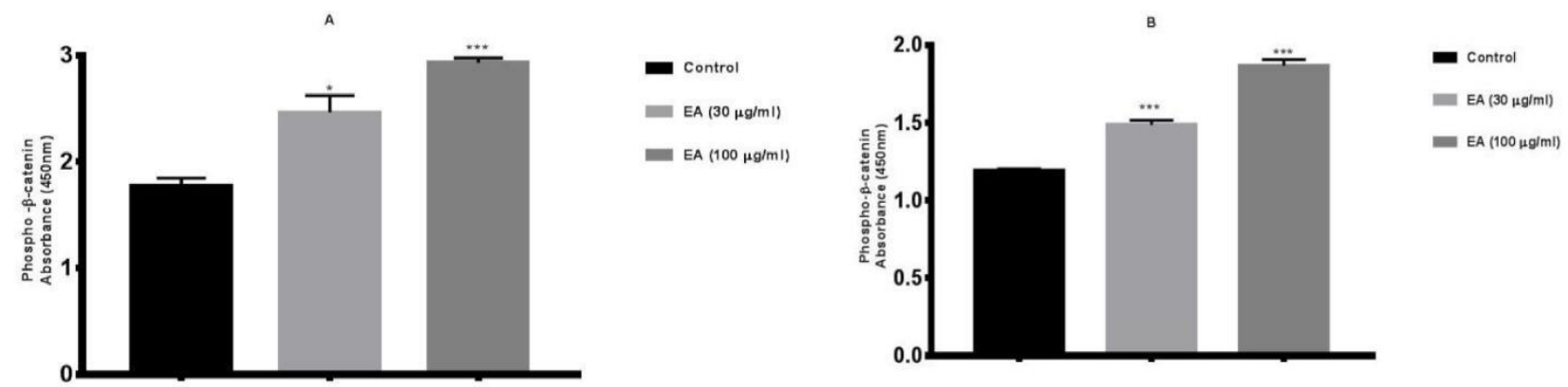

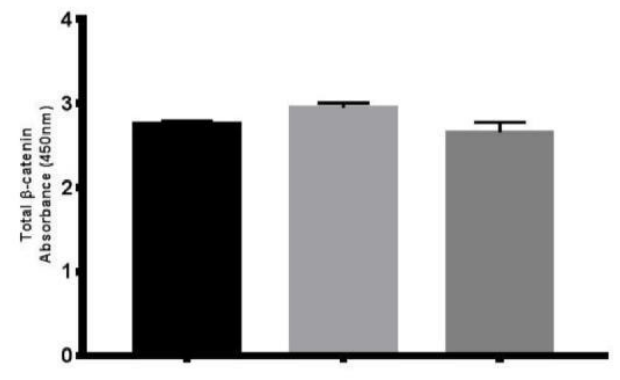

HCT-116 cells
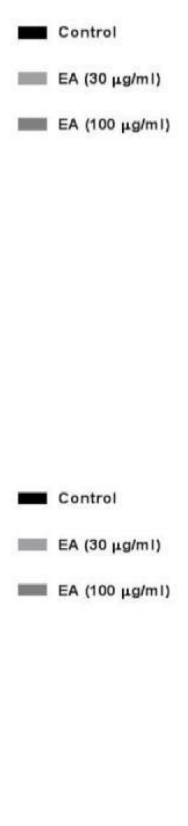

Figure 3: Regulation of $\beta$-catenin phosphorylation by ellagic acid in HCT-116 and CaCo-2 cells. Incubation of HCT-116 (A) and CaCo-2 (B) cell lines with ellagic acid $(100 \mu \mathrm{g} / \mathrm{ml})$ for 24 hours resulted in a significant increase in the level of phospho- $\beta$-catenin as indicated by the increase in the absorbance values in ellagic acid-treated cells $(\mathrm{p}=0.0002$ and 0.0001$)$. Significant increase in phosphorylation was also elicited in HCT-116 and CaCo- 2 cells by the lower concentration $(30 \mu \mathrm{g} / \mathrm{ml})(\mathrm{p}=0.017$ and 0.0008$)$. There was no obvious change in the level of total $\beta$-catenin in both cell types. The basal level of phospho- $\beta$-catenin was higher in HCT-116 cells. $\beta$-catenin levels were estimated by ELISA and values are means of triplicate sets 
4- Incubation of HCT-116 and CaCo-2 cells resulted in reduction of cytochrome 1B1 levels in both cell types:

The results depicted in Figure $4 \mathrm{~A}$ and $\mathrm{B}$ and table 7 show the effect of ellagic acid treatment on the level of cytochrome 1B1 in HCT-116 (A) and $\mathrm{CaCo}-2$ (B) cell lines. Incubation of $\mathrm{CaCo}-2$ cells with ellagic acid $(30 \mu \mathrm{g} / \mathrm{ml})$ for 48 hours resulted in an apparent reduction in cytochrome 1B1 levels when compared to the corresponding control cells $(p=0.227)$. Increasing the dose to $100 \mu \mathrm{g} / \mathrm{ml}$ ) resulted in a significant reduction in cytochrome 1B1 concentration $(\mathrm{p}=0.0001)$. The impact of the drug on cytochrome 1B1 concentration in HCT-116 cells was similar to that observed in CaCo-2 cells. Both drug concentrations produced a significant reduction in cytochrome 1B1 levels when compared to the corresponding control cells $(\mathrm{p}=0.0257$ and 0.0007). It was obvious that the lower concentration of ellagic acid did not produce a remarkable change in cytochrome 1B1 level, particularly in $\mathrm{CaCo}-2$ cells (results are the mean values of triplicate sets).

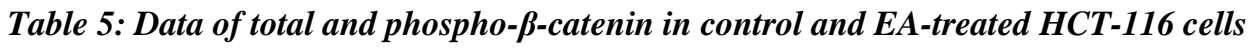

\begin{tabular}{|l|c|c|c|c|c|c|}
\hline \multicolumn{1}{|c|}{ Cell line } & \multicolumn{2}{|c|}{ HCT-116/Phospho- $\boldsymbol{\beta}$-catenin } & \multicolumn{3}{c|}{ HCT-116/total- $\boldsymbol{\beta}$-catenin } \\
\hline $\begin{array}{l}\text { Ellagic } \\
\text { concentration }(\boldsymbol{\mu g} / \mathbf{m l})\end{array}$ & $\mathbf{0 . 0}$ & $\mathbf{3 0}$ & $\mathbf{1 0 0}$ & $\mathbf{0 . 0}$ & $\mathbf{3 0}$ & $\mathbf{1 0 0}$ \\
\hline Absorbance & 1.9145 & 2.644 & 2.864 & 2.792 & 3.057 & 2.403 \\
& 1.7275 & 2.145 & 2.916 & 2.681 & 2.921 & 2.784 \\
\cline { 2 - 8 } & 1.68173 & 2.601 & 3.012 & 2.795 & 2.869 & 2.77 \\
\hline Mean \pm S.D & $\mathbf{1 . 7 7} \pm$ & $\mathbf{2 . 4 6 3} \pm$ & $\mathbf{2 . 9 3 1} \pm$ & $\mathbf{2 . 7 5 6} \pm \mathbf{0 . 0 6 5}$ & $\mathbf{2 . 9 4 9} \pm$ & $\mathbf{2 . 6 5 2} \pm$ \\
& $\mathbf{0 . 1 2 3}$ & $\mathbf{0 . 2 7 6}$ & $\mathbf{0 . 0 7 5}$ & & $\mathbf{0 . 0 9 7}$ & $\mathbf{0 . 2 1 6}$ \\
\hline
\end{tabular}

Table 6: Data of total and phospho- $\beta$-catenin in control and EA-treated CaCo-2 cells

\begin{tabular}{|l|c|c|c|c|c|c|}
\hline \multicolumn{1}{|c|}{ Cell line } & \multicolumn{2}{|c|}{ CaCo-2 /Phospho- $\beta$-catenin } & \multicolumn{3}{c|}{ CaCo-2 /total- $\beta$-catenin } \\
\hline $\begin{array}{l}\text { Ellagic } \\
\text { concentration }(\boldsymbol{\mu g} / \mathbf{m l})\end{array}$ & $\mathbf{0 . 0}$ & $\mathbf{3 0}$ & $\mathbf{1 0 0}$ & $\mathbf{0 . 0}$ & $\mathbf{3 0}$ & $\mathbf{1 0 0}$ \\
\hline Absorbance & 1.216 & 1.434 & 1.931 & 2.645 & 2.293 & 2.51 \\
& 1.182 & 1.49 & 1.88 & 2.691 & 2.8145 & 2.562 \\
\cline { 2 - 8 } & 1.179 & 1.537 & 1.793 & 2.901 & 2.51 & 2.718 \\
\hline Mean \pm S.D & $\mathbf{1 . 1 9 2 \pm}$ & $\mathbf{1 . 4 8} \pm$ & $\mathbf{1 . 8 6 8} \pm$ & $\mathbf{2 . 7 4 6} \pm \mathbf{0 . 1 3 6}$ & $\mathbf{2 . 5 3 9 \pm}$ & $\mathbf{2 . 5 9 7 \pm}$ \\
& $\mathbf{0 . 0 2 0 5}$ & $\mathbf{0 . 0 5 1 5}$ & $\mathbf{0 . 0 6 9}$ & & $\mathbf{0 . 2 6 2}$ & $\mathbf{0 . 1 0 8}$ \\
\hline
\end{tabular}

Table 7: Concentration of CY $1 B 1$ in control and EA-treated CaCo-2 and HCT-116 cells.

\begin{tabular}{|c|c|c|c|c|c|c|}
\hline Cell line & \multicolumn{3}{|c|}{ CaCo-2 } & \multicolumn{3}{|c|}{ НCT-116 } \\
\hline $\begin{array}{l}\text { Ellagic } \quad \begin{array}{c}\text { acid } \\
\text { concentration }(\mu \mathrm{g} / \mathrm{ml})\end{array}\end{array}$ & 0.0 & 30 & 100 & 0.0 & 30 & 100 \\
\hline \multirow{3}{*}{$\begin{array}{l}\text { CY 1B1 concentration } \\
(\mathrm{ng} / \mathrm{ml})\end{array}$} & 52.26 & 43.1 & 30.81 & 66.297 & 53.909 & 41.548 \\
\hline & 48.59 & 45.3 & 32.1 & 61.117 & 51.613 & 36.930 \\
\hline & 50.91 & 51.58 & 29.59 & 59.542 & 56.178 & 37.677 \\
\hline Mean \pm S.D & $\begin{array}{c}50.59 \pm \\
1.856\end{array}$ & $\begin{array}{c}49.66 \pm \\
4.401\end{array}$ & $\begin{array}{l}30.83 \pm \\
1.255\end{array}$ & $62.32 \pm 3.534$ & $\begin{array}{r}53.9 \\
\pm 2.283\end{array}$ & $\begin{array}{c}38.72 \\
\pm 2.479\end{array}$ \\
\hline
\end{tabular}

\section{Discussion:}

The broad-spectrum anti-tumor effects of ellagic acid have been investigated on multiple levels in many human cancers including colon. We have recently reported the anti-oncogenic influence of ellagic acid in HCT-116 and CaCo-2 cells that was mediated by down-regulation of K-Ras oncogene, 
an effect that matched K-Ras silencing by si-RNA (14). These observations were also supported by another finding that confirmed similar anti-cancer effects in colon cancer leptin-enriched microenvironment (15). For further examination of EA potential in colon cancer model, the effect of ellagic acid on beta-catenin and cytochrome $\mathrm{p} 450$ (1B1) was investigated in both cell types (HCT116 and CaCo-2 cells). Beta-catenin role in cell adhesion and migration has been reportedly associated with increased risk of poor prognosis and metastasis explaining its overexpression in many cancers and representing it as a potential therapeutic target (16). In the same context, overexpression of cytochrome $1 \mathrm{~b} 1$ favors cancer survival and protection against chemotherapeutic agents $(11,12,17)$. Therefore overexpression of cytochrome $1 \mathrm{~b} 1$ has been reported in many human cancers and was associated with overall worse progression and lower survival rates (18). Beta catenin level is regulated by phosphorylation, which directs the protein towards degradation by the Ubiquitin-proteasome system (19). In this regard, treating HCT-116 and $\mathrm{CaCo} 2$ cells with EA $(30 \mu \mathrm{g} / \mathrm{ml})$ resulted in an apparent increase in levels of phosphorylated beta catenin when compared to the corresponding control (Figure 3). Increasing the dose to $100 \mu \mathrm{g} / \mathrm{ml}$ resulted in further increase in beta catenin phosphorylation, though this was not much increase when compared to those cells incubated with the lower concentration. This influence favors degradation of beta-catenin and reduces its levels in cells. In agreement with these findings, Anitha and colleagues (20) have reported the ability of EA to block oral carcinogenesis development by downregulating Wnt/beta-catenin and $\mathrm{NF} \kappa \mathrm{B}$ signaling pathways. These results are also in concordance with the reported anti-tumor potential of EA derivatives in colon cancer models and confirming our results (21). Also, EA treatment resulted in a remarkable reduction in the levels of cytochrome 1B1 when compared to the corresponding control cells in both cell types (Figure 4). Increasing doses of EA have further reduced cytochrome 1B1 in HCT-116, while in CaCo-2 cells; there was no noticeable difference between the effects of EA (30 $\mu \mathrm{g} / \mathrm{ml})$ and the corresponding control. In line with our finding, the ability of EA to suppress in vivo mammary carcinogenesis by attenuation of cytochrome 1B1 was reported, an action contributed to prevention of estrogen metabolism (22). The results of the present study altogether were also consistent with the ability of EA (50 $\mu \mathrm{g} / \mathrm{ml}$ ) to derail cell cycle progression in HCT-116 and $\mathrm{CaCo}-2$ cells by inducing cell death and cell cycle arrest in G1 phase (Figure 2). A significant increase of cell population in sub-G1 phase was observed in EA-treated $\mathrm{CaCo}-2$ cells in comparison to the corresponding non-treated cells and zero-time cells. A non-significant increase in sub-G1 cell population number was also observed following treatment of HCT-116 cells with EA. There was no significant difference in the number of cells in G1 phase between zero-time and control cells and those cells treated with EA suggesting arresting of cells in this phase. A similar antiproliferative effect involving down-regulation of the cell survival pathway, PI3K/Akt, induction of apoptosis by up-regulation of Bax protein and caspase 3 activities was reported in dimethyl hydrazine (DMH)-induced colon cancer model (23). Another study (24) has further supported our observations by reporting that pomegranate juice 

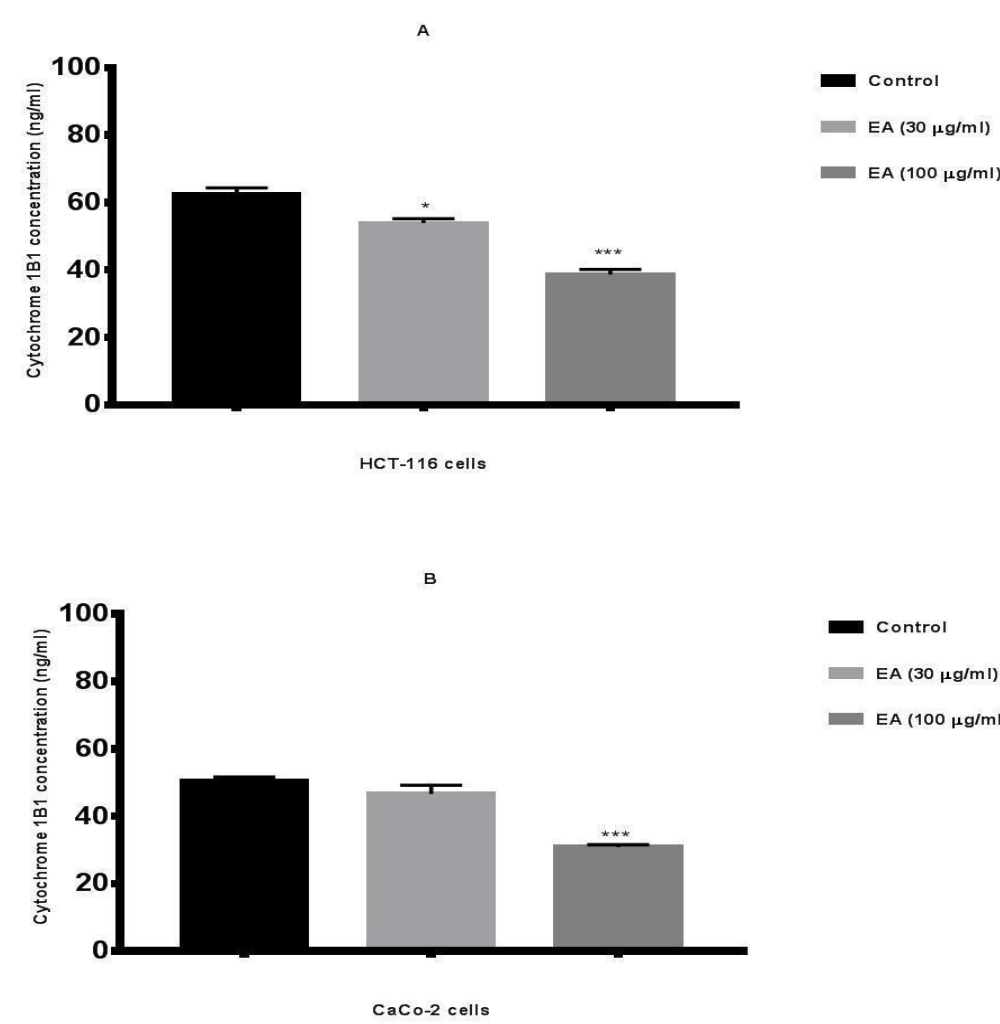

derivative and EA counterpart, ellagitannins inhibited HT-29 colon cancer cell proliferation by inducing apoptosis and cell cycle arrest. The overall conclusion of the current study and the previously reported information further support the multifactorial nature of the anti-colon cancer influence of EA. This antitumor potential of EA makes it an excellent candidate for drug development providing different strategies to tackle colon cancer with different genetic makeup, as well as other cancers.

\section{References}

1. Sharma M, Li L, Celver J, Killian C, Kovoor A, Seeram NP. Effects of Fruit Ellagitannin Extracts, Ellagic Acid, and Their Colonic Metabolite, Urolithin A, on Wnt Signaling. Journal of agricultural and food chemistry. 58(7):3965-9; 2010
Figure 4: Ellagic acid treatment reduced cytochrome 1B1 levels in HCT-116 and CaCo-2 cell types. Results depicted in Figure 4 A (HCT116 cells) and $\mathrm{B}$ (CaCo-2 cells) show the concentrations of cytochrome 1B1 in cells treated with Medium or ellagic acid (30 or 100 $\mu \mathrm{g} / \mathrm{ml}$ ). Cytochrome 1B1 concentration was significantly reduced upon incubation of HCT116 with ellagic acid (30 $\mu \mathrm{g} / \mathrm{ml} ; \mathrm{p}=0.0257)$ or $(100 \mu \mathrm{g} / \mathrm{ml} ; \mathrm{p}=0.0007)$. A significant reduction in cytochrome 1B1 levels was also observed in CaCo-2 cells incubated ellagic acid $(100 \mu \mathrm{g} / \mathrm{ml}$; $\mathrm{p}=0.0001$ ); meanwhile, the lower concentration failed to elicit a significant reduction $(\mathrm{p}=$ 0.227). Cytochrome 1B1 level was estimated by ELISA and values are means of triplicate sets.

2. Wang Y, Qiu Z, Zhou B, Liu C, Ruan J, Yan Q, et al. In vitro antiproliferative and antioxidant effects of urolithin $\mathrm{A}$, the colonic metabolite of ellagic acid, on hepatocellular carcinomas HepG2 cells. Toxicology in vitro : an international journal published in association with BIBRA. 29(5):1107-15, 2015.

3. Zhang H-M, Zhao L, Li H, Xu H, Chen W-W, Tao L. Research progress on the anticarcinogenic actions and mechanisms of ellagic acid. Cancer Biology \& Medicine. 11(2):92-100, 2014.

4. Vanella L, Di Giacomo C, Acquaviva R, Barbagallo I, Cardile V, Kim DH, et al. Apoptotic markers in a prostate cancer cell line: effect of ellagic acid. Oncology reports.30 (6):2804-10, 2013. 
5. Wang N, Wang Q, Tang H, Zhang F, Zheng $\mathrm{Y}$, Wang $\mathrm{S}$, et al. Direct inhibition of ACTN4 by ellagic acid limits breast cancer metastasis via regulation of $\beta$-catenin stabilization in cancer stem cells. Journal of Experimental \& Clinical Cancer Research : CR. 36:172, 2017

6. Pandurangan AK. Potential targets for prevention of colorectal cancer: a focus on $\mathrm{PI} 3 \mathrm{~K} / \mathrm{Akt} / \mathrm{mTOR}$ and Wnt pathways. Asian Pacific journal of cancer prevention : APJCP. 14(4):22015,2013

7. Lee HC, Kim M, Wands JR. Wnt/Frizzled signaling in hepatocellular carcinoma. Frontiers in bioscience : a journal and virtual library. 11:190115,2006

8. Borowsky AD, Bandhuvula P, Kumar A, Yoshinaga Y, Nefedov M, Fong LG, et al. Sphingosine-1-phosphate lyase expression in embryonic and adult murine tissues. Journal of lipid research. 53(9):1920-31, 2012.

9. Kang YJ, Park HJ, Chung HJ, Min HY, Park EJ, Lee MA, et al. Wnt/beta-catenin signaling mediates the antitumor activity of magnolol in colorectal cancer cells. Molecular pharmacology. 82(2):168-77, 2012.

10. Symolon H, Bushnev A, Peng Q, Ramaraju H, Mays SG, Allegood JC, et al. Enigmol: a novel sphingolipid analogue with anticancer activity against cancer cell lines and in vivo models for intestinal and prostate cancer. Molecular cancer therapeutics. 10(4):648-57, 2011

11. Su JM, Lin $\mathrm{P}$, Wang CK, Chang $\mathrm{H}$. Overexpression of cytochrome P450 1B1 in advanced non-small cell lung cancer: a potential therapeutic target. Anticancer research. 29(2):509$15,2009$.

12. Gibson P, Gill JH, Khan PA, Seargent JM, Martin SW, Batman PA, et al. Cytochrome P450 1B1 (CYP1B1) is overexpressed in human colon adenocarcinomas relative to normal colon: implications for drug development. Molecular cancer therapeutics. 2(6):527-34, 2003

13. Patel SA, Bhambra U, Charalambous MP, David RM, Edwards RJ, Lightfoot $\mathrm{T}$, et al. Interleukin-6 mediated upregulation of CYP1B1 and CYP2E1 in colorectal cancer involves DNA methylation, miR27b and STAT3. British journal of cancer.111(12):2287-96, 2014

14. Yousef AI, El-Masry OS, Abdel Mohsen MA. Impact of Cellular Genetic Make-up on Colorectal Cancer Cell Lines Response to Ellagic Acid: Implications of Small Interfering RNA. Asian Pacific journal of cancer prevention: APJCP. 17(2):743-8, 2016

15. Yousef AI, El-Masry OS, Yassin EH. The anti-oncogenic influence of ellagic acid on colon cancer cells in leptin-enriched microenvironment. Tumour biology : the journal of the International Society for Oncodevelopmental Biology and Medicine.37(10):13345-53, 2016

16. Han J, Gao B, Jin X, Xu Z, Li Z, Sun Y, et al. Small interfering RNA-mediated downregulation of beta-catenin inhibits invasion and migration of colon cancer cells in vitro. Medical science monitor : international medical journal of experimental and clinical research. 18(7):BR273-80, 2012

17. McFadyen MC, Cruickshank ME, Miller ID, McLeod HL, Melvin WT, Haites NE, et al. 
Cytochrome P450 CYP1B1 over-expression in primary and metastatic ovarian cancer. British journal of cancer. 85(2):242-6., 2001.

18. Bruno RD, Njar VCO. Targeting Cytochrome P450 Enzymes: A New Approach in Anti-cancer Drug Development. Bioorganic \& medicinal chemistry. 15(15):5047-60, 2007

19. Gao C, Xiao G, Hu J. Regulation of Wnt/ $\beta$-catenin signaling by posttranslational modifications. Cell \& Bioscience. 4:13-., 2014

20. Anitha P, Priyadarsini RV, Kavitha K, Thiyagarajan P, Nagini S. Ellagic acid coordinately attenuates Wnt/beta-catenin and NFkappaB signaling pathways to induce intrinsic apoptosis in an animal model of oral oncogenesis. European journal of nutrition.52(1):75-84, 2013.

21. Ramirez de Molina A, Vargas T, Molina S, Sanchez J, Martinez-Romero J, GonzalezVallinas M, et al. The ellagic acid derivative 4,4'di-O-methylellagic acid efficiently inhibits colon cancer cell growth through a mechanism involving WNT16. The Journal of pharmacology and experimental therapeutics.353(2):433-44, 2015

22. Aiyer HS, Gupta RC. Berries and ellagic acid prevent estrogen-induced mammary tumorigenesis by modulating enzymes of estrogen metabolism. Cancer Prev Res (Phila).3(6):727-37, 2010

23. Umesalma S, Sudhandiran G. Ellagic acid prevents rat colon carcinogenesis induced by 1,2 dimethyl hydrazine through inhibition of AKTphosphoinositide-3 kinase pathway. European journal of pharmacology. 660(2-3):249-58, 2011
24. Kasimsetty SG, Bialonska D, Reddy MK, Ma G, Khan SI, Ferreira D. Colon cancer chemopreventive activities of pomegranate ellagitannins and urolithins. Journal of agricultural and food chemistry. 58(4):2180-7, 2010 